\title{
RESEARCH Note \\ Use of organic and inorganic fertilization in zero- discharge tanks and ponds and its effects on plankton and shrimp Litopenaeus vannamei performance
}

\author{
Uso de fertilización orgánica e inorgánica en tanques y estanques con cero \\ recambio de agua y sus efectos en el plancton y desempeño productivo \\ del camarón Litopenaeus vannamei

\section{Héctor M. Esparza-Leal ${ }^{1}$, Jesús T. Ponce-Palafox ${ }^{2}$, Guillermo F. Lara-Anguiano $^{3}$, Wenceslao Valenzuela-Quiñónez ${ }^{1}$, Píndaro Álvarez-Ruíz ${ }^{1}$ and Ely S. López-Álvarez ${ }^{1}$}

\begin{abstract}
'Instituto Politécnico Nacional-CIIDIR Unidad Sinaloa, Boulevard Juan de Dios Bátiz Paredes \# 250, Guasave, Sinaloa 81101, México.*Corresponding author: hesparza@ipn.mx

${ }^{2}$ Universidad Autónoma de Nayarit, CENITT-CBAP, Laboratorio de Bioingeniería Costera, Escuela Nacional de Ingeniería Pesquera, Ciudad de la Cultura Amado Nervo, Tepic, Nayarit 62155, México

${ }^{3}$ Maestría en Recursos Naturales y Medio Ambiente Program, IPN-CIIDIR Unidad Sinaloa, Boulevard Juan de Dios Bátiz Paredes \# 250, Guasave, Sinaloa 81101, México
\end{abstract}

\begin{abstract}
The aim of this study was to investigate the effects of organic (molasses) and inorganic (Nutrilake ${ }^{*}$ ) fertilization on plankton, water quality, and shrimp Litopenaeus vannamei performance reared in zero-discharge tanks and ponds. The findings showed that in tanks, the organic fertilization induced highest survival and production, and low total ammonia- $\mathrm{N}$ concentration; however, this effect was not observed in the ponds. In both tanks and ponds, the inorganic fertilization increased nitrogen levels. The phytoplankton abundance increased in both tanks/ponds with the fertilization treatments. Shrimp production in the tanks and ponds fertilized almost doubled compared with unfertilized treatments.
\end{abstract}

Key words: Litopenaeus vannamei, fertilization, plankton, production

\section{INTRODUCTION}

To mitigate the environmental impact of effluent discharge and to prevent the introduction of contaminants and pathogens into the water supply, some shrimp farmers have evolved from open systems with frequent water discharge, to closed systems with limited water discharge. The main problem with closed systems is rapid eutrophication, which could increases the nutrient concentrations to unsuitable levels for shrimp farming (Thakur $\&$ Lin 2003). However, some authors report that shrimp cultures without water exchange, might be maintained by growing heterotrophic bacteria and plankton using carbon or nitrate compounds to boost the elimination of waste (Boyd 1997, Samocha et al. 2007).

The addition of carbon compounds to shrimp pond waters can stimulate ammonia uptake by heterotrophic bacteria, in marine water (Wheeler \& Kirchman 1986, Samocha et al. 2007), and provide single-cell sources of protein (Avnimelech et al. 1989). The molasses play an important role in shrimp farming, since it has been widely used as carbon source for denitrification, anaerobic fermentation, and aerobic waste conversion (Samocha et al. 2007). On another hand, natural food sources may also be increased by inorganic fertilization, contributing more than $50 \%$ of the nutrition of Litopenaeus vannamei (Janeo et al. 2009). Therefore, the fertilization with Nutrilake $^{\circledR}$ (also known as Chilean saltpeter) in shrimp ponds could have several environmental and economic benefits, because the Nutrilake ${ }^{\circledR}$ is a good source of nitrogen (Boyd 1997). Thus, this study was aimed at determining whether the addition of carbon or nitrogen via the application of molasses and Nutrilake ${ }^{\circledR}$, respectively, can reduce environmental ammonia concentrations, stimulate plankton production, and which strategy (Nutrilake ${ }^{\circledR}$, molasses or unfertilized) is the most efficient at improving shrimp production in zero-discharge tanks and ponds.

\section{Materials AND Methods}

\section{STUDY SITE AND EXPERIMENTAL DESIGN}

Two parallel experiments using juvenile L. vanname $i$ were conducted in outdoor tanks and in ponds of a commercial shrimp 
farm. The fertilization treatments at both sites were as follows: (1) $0.5 \mathrm{~g} \mathrm{~m}^{-3}$ per week of the inorganic fertilizer Nutrilake ${ }^{\circledR}(14.5-$ 6-0 inorganic fertilizer with $3.5 \% \mathrm{SiO}_{2}$ and $23 \% \mathrm{Na}$; Nutrilake ${ }^{\circledR}$, SQM Nitratos de Mexico), (2) $1.25 \mathrm{~g} \mathrm{~m}^{-3}$ per week of locally purchased sugar cane-derived molasses, and (3) the unfertilized control. The amount of molasses added was based on unpublished data and a report of Avnimelech (1999). Three tank replicates and two pond replicates were randomly assigned for each treatment. The study ended at 75 days.

\section{TANKS STUDY}

Each treatment (Nutrilake ${ }^{\circledR}$, molasses, and control) was applied to three rectangular plastic tanks ( $2 \mathrm{~m} \times 1 \mathrm{~m} \times 1 \mathrm{~m}$ ). Juvenile shrimp $(4.0 \pm 0.3 \mathrm{~g})$ from the on-farm ponds, without evidence of disease or parasites were reared in each tank at a stocking density of 20 org $\mathrm{m}^{-2}$.

The Nutrilake ${ }^{\circledast}$ and molasses were weighed and dissolved in marine water prior to their addition to each experimental unit. Each solution was added once per week until study end. The control treatment was conducted under the same conditions as the fertilization treatments.

The shrimp were reared under a natural light regime $(\approx 14: 10$ h, light:dark). Each tank was aerated with two airstones. Throughout the experiment, the tanks were maintained with zero-water exchange. The shrimp were fed twice daily with commercial shrimp pellets (35\% crude protein; Purina ${ }^{\mathrm{MR}}$, Mexico). The feeding rate was gradually adjusted each week (16-3\% body weight per day), based on feed consumption and shrimp body weight. The shrimp growth was estimated each week. After 75 days of culture, the shrimp were harvested, and the survival rate, production, and feed conversion rate (FCR) were estimated. Specific growth rate (SGR, \% body weight $\mathrm{d}^{-}$ $\left.{ }^{1}\right)$ was calculated from $\mathrm{SGR}=100[(\mathrm{Ln} \mathrm{Wf}-\mathrm{Ln} \mathrm{Wi})] / \mathrm{t}$, where $\mathrm{Wf}=$ mean weight at the end of the period, $\mathrm{Wi}=$ mean weight at the beginning of the period, and $\mathrm{t}=$ time in days of the period.

\section{Ponds STudy}

Six earthen ponds ( 1 ha each, two replicates per treatment) were selected for the on-farm experiment. The ponds for the fertilization (Nutrilake ${ }^{\circledR}$ and molasses), and control treatments were subjected to the usual pre-stocking procedures (MartínezCórdova 1999). Throughout the experimental period, the ponds were maintained with zero-water exchange, except for water that was added to maintain the water level. Shrimp L. vannamei postlarvae $(0.014 \pm 0.001 \mathrm{~g})$ were purchased from a commercial hatchery, and stocked in each experimental pond at a density of $10 \mathrm{org}$. $\mathrm{m}^{-2}$. The pond experiment began after 36 days, when the shrimp weighed $4.0 \pm 0.4 \mathrm{~g}$, and the stocking density was approximately 9 org. $\mathrm{m}^{-2}$. Prior to starting the experiment, sampling was carried out to estimate the population density of each pond (Anónimo 1998).

The Nutrilake ${ }^{\circledR}$ and molasses were dissolved and applied as in the tanks study. The control treatment was conducted under the same conditions as the fertilization treatments. The feed ratio was gradually adjusted each week (16-3\% body weight per day). Each week was estimated the biomass and average weight. After 75 day of culture, the shrimp performance was estimated.

\section{Physicochemical parameters and Plankton analyses}

During both experiments (tanks/ponds), the $\mathrm{pH}$, dissolved oxygen (DO), and temperature were recorded twice a day. Twice monthly, in each tank and pond was analyzed the nitrite, nitrate, total ammonia, and phosphate using the methods described by Strickland \& Parsons (1972).

Phytoplankton and zooplankton abundances of each tank and pond were estimated fortnightly. Phytoplankton abundance (cells $\mathrm{mL}^{-1}$ ) was estimated using an optical microscopic (Zeiss, $40 \mathrm{X}$ ) according to the method proposed by Newell \& Newell (2006). The keys and illustrations proposed of Sournia (1978), Tomas (1997), and Hallegraeff et al. (2003) were used as references for taxa identification. Zooplankton were counted (ind. $\mathrm{L}^{-1}$ ) and identified using a Sedwick-Rafter chamber ${ }^{\circledR}$ (Wildlife Supply Co. Buffalo, NY, USA) on a stereo-microscope (Zeiss, 10X and 40X). Zooplankton were identified according to major taxonomic groups with reference keys (Todd et al. 1996, Newell \& Newell 2006).

\section{Statistical analyses}

The homoscedasticity of the variances and the normality of all data were first veried. Treatment effects on physicochemical parameters and on plankton counts of all study were evaluated by two-way repeated measures ANOVA with treatment (separate tanks to ponds) as the main factor, and the sampling date as the repeated measures factor. Treatment effects on shrimp performance was evaluated using one-way ANOVA. Significant differences within tanks or ponds were tested with Tukey's multi-comparison test of means. The statistical analyses were evaluated with a $5 \%$ of significance level using STATISTICA package v6 (StatSoft, Tulsa, OK, USA). The survival data were transformed (arcsine of the square root) before analysis (Zar 1996).

\section{Results AND Discussion}

In both tanks ( 20 org. $\mathrm{m}^{-2}$ ) and pond ( 9 org. $\mathrm{m}^{-2}$ ) experiments, fertilization with Nutrilake ${ }^{\circledR}$ and molasses in zero-water exchange 


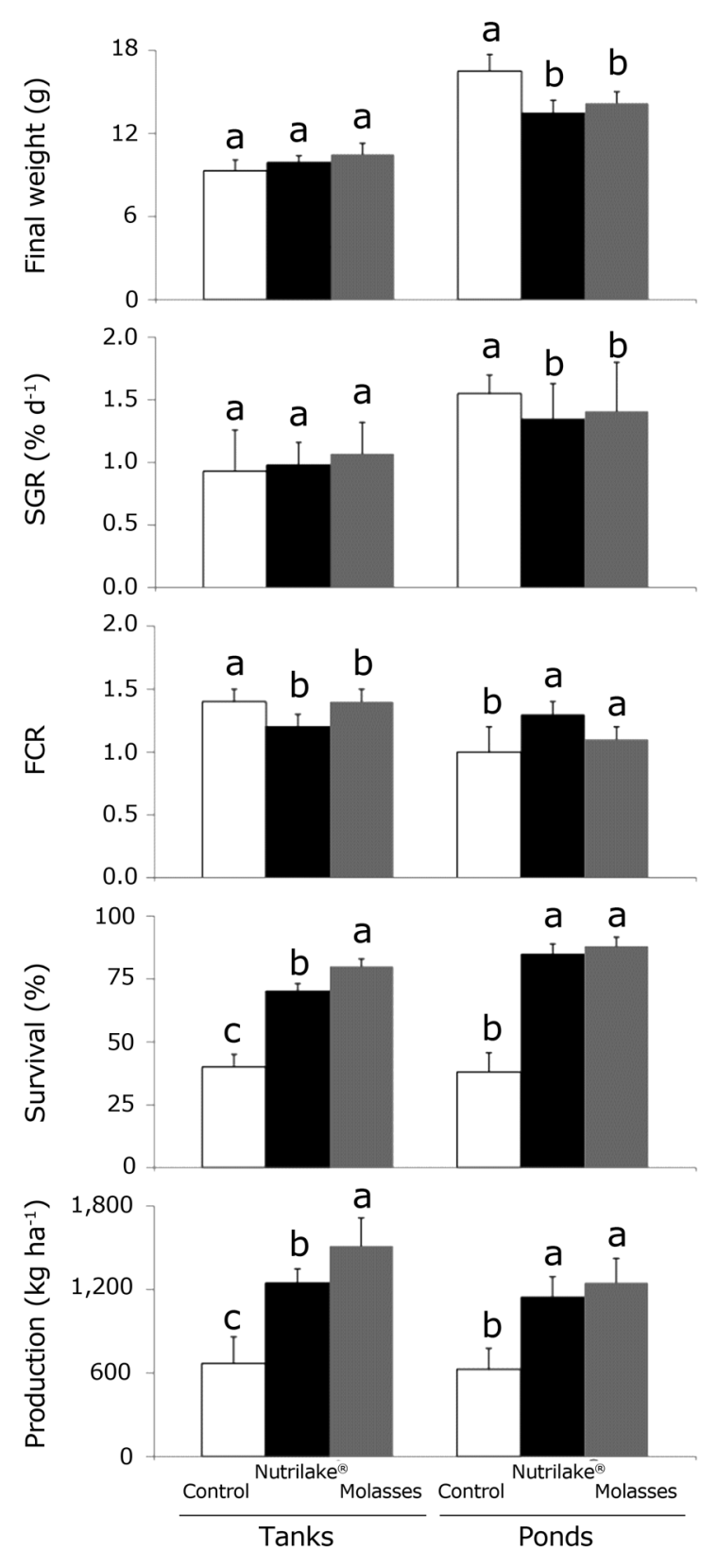

Figure 1. Performance parameters (mean $\pm \mathrm{SE}$ ) of shrimp Litopenaeus vannamei reared in tanks ( 20 org. $\mathrm{m}^{-2}$ ) and ponds $\left(9\right.$ org. $\mathrm{m}^{-2}$ ) with different fertilization treatment. Bars with different superscripts differ significantly within each study $(\mathrm{P}<0.05)$. The production values of the tanks were extrapolated from $\mathrm{kg} \mathrm{m}^{-2} /$ Parámetros productivos (media $\pm \mathrm{EE}$ ) del camarón Litopenaeus vannamei cultivado en tanques ( $20 \mathrm{org} . \mathrm{m}^{-2}$ ) y estanques ( $9 \mathrm{org} . \mathrm{m}^{-2}$ ) con diferente tratamiento de fertilización. Letras diferentes entre las barras indica diferencias significativas dentro de cada estudio $(P<0,05)$. Los valores de producción de los tanques fueron extrapolados de $\mathrm{kg} \mathrm{m}^{-2}$ systems were found to have a positive effect on shrimp survival and production compared to the unfertilized treatments (Fig. 1). The observation that highest shrimp survival and production occurred in the molasses-treated tanks is consistent with others reports (Samocha et al. 2007).

Although, not mass mortality of shrimp was observed lower shrimp survival rates were more evident in the unfertilized groups of ponds ( $38 \pm 7.6 \%$; Fig. 1$)$. These findings suggest that both fertilizers used in this work might be beneficial for shrimp culture, and in tanks, the fertilization with molasses generates higher survival as already reported (Samocha et al. 2007). The final mean weight of shrimp obtained in the tanks and ponds experiments were similar among fertilized groups $(\approx 10.2 \pm 0.7$ and $13.9 \pm 0.9$ in tanks and ponds, respectively), indicating that the fertilizers Nutrilake ${ }^{\circledR}$ and molasses produced similar conditions for shrimp growth in stocking densities of 9 and 20 org. $\mathrm{m}^{-2}$ (Fig. 1). However, the growth rate results obtained in this study $\left(\operatorname{tanks}=0.45 \mathrm{~g} \mathrm{week}^{-1}\right.$; ponds $\left.=0.83 \mathrm{~g} \mathrm{week}^{-1}\right)$ were lower than other reports $\left(\approx 1.0 \mathrm{~g} \mathrm{week}^{-1}\right.$; Venero et al. 2007, Ray et al. 2011). Although lower final mean weights were expected in the unfertilized groups, no significant differences between fertilized and unfertilized groups were observed in the tank experiment where the initial stocking density was 20 org. $\mathrm{m}^{-2}\left(\right.$ Nutrilake $^{\circledR}=9.9 \pm 0.5 \mathrm{~g}$, Molasses $=10.5 \pm 0.8 \mathrm{~g}$, and unfertilized $($ control $)=9.3 \pm 0.8 \mathrm{~g}$; Fig. 1]. In the ponds experiment where the initial stocking density was 9 org. $\mathrm{m}^{-2}$ a higher mean weight was observed in the unfertilized group $(16.5$ $\pm 1.2 \mathrm{~g}$ ). In both cases, the low survival affected the growth (< 40\%; Fig. 1; Wang et al. 1998), but in the ponds the combination of lower density and survival impacted more. On another hand, shrimp growth may have been the result of high zooplankton abundance that occurred in the unfertilized ponds, the zooplankton perhaps contributing significantly to shrimp nutrition and growth, as reported in others studies (Allan et al. 1995, Shishehchian \& Yussof 1999). In the tanks study, both fertilized and unfertilized groups exhibited similar zooplankton abundances (Fig. 2).

In both the tanks and ponds experiments, the dominant zooplankton taxon was copepod (> 60\%), except in the unfertilized groups of pond study, where the dominant taxa was rotifer (> 80\%; Fig. 2), these results are consistent with previous reports in relation to biota in low water exchange ponds farming (Martínez-Córdova et al. 2002).

The dominant phytoplankton taxa differed between tanks (chlorophyte-cyanobacteria) and ponds (cyanobacteriadiatom) experiments, but these there were not modified by the treatments (Fig. 3), and the taxa composition in both experiments 

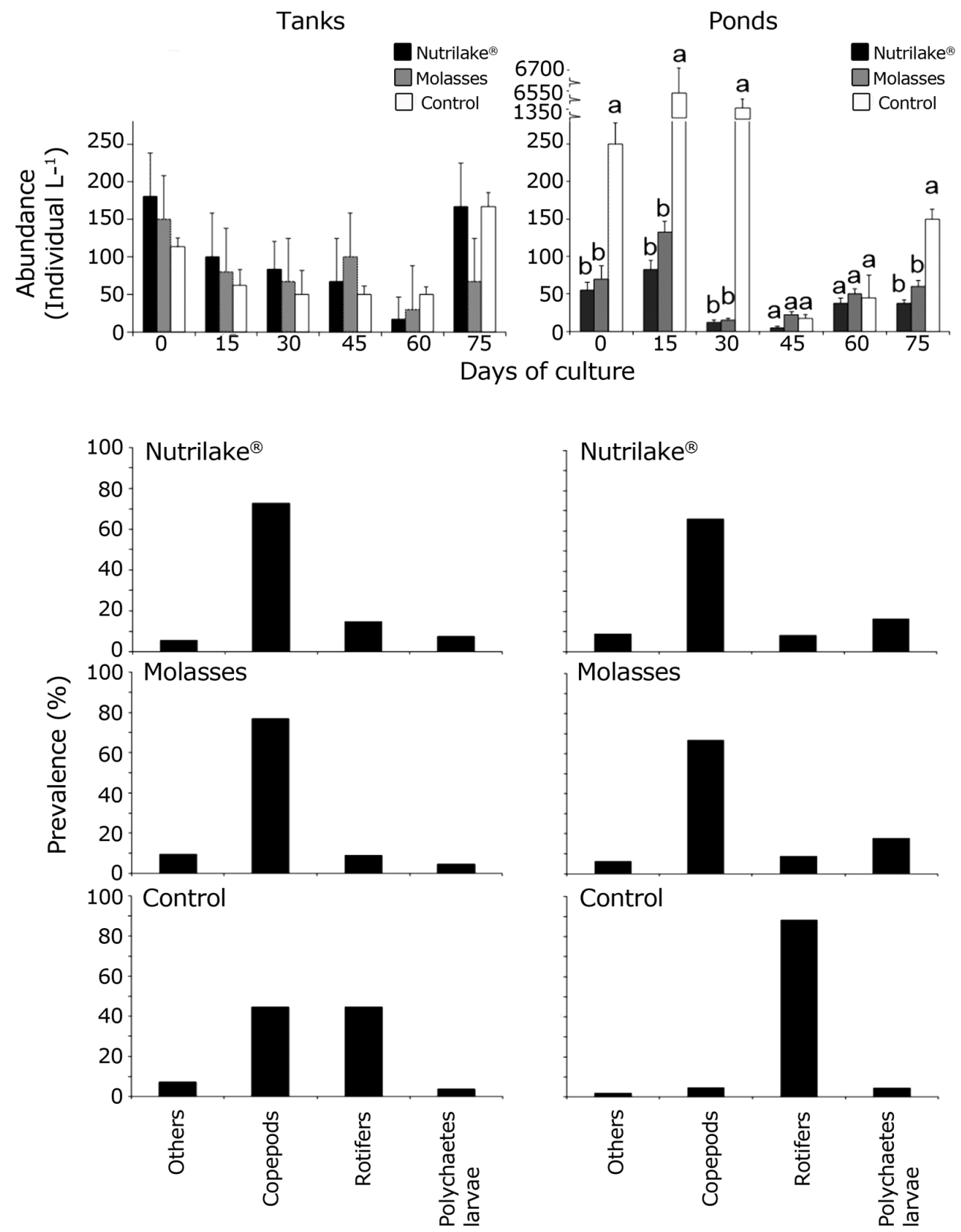

Dominant zooplankton taxa

Figure 2. Zooplankton abundance (mean $\pm \mathrm{SE}$ ) and dominant zooplankton taxa (means) in the shrimp culture water under different fertilization treatments. The letters that differ among the bars in the first graph of ponds indicate significant differences $(\mathbf{P}<\mathbf{0 . 0 5})$ / Abundancia de zooplancton (media $\pm \mathrm{EE}$ ) y taxones dominantes de zooplancton (promedios) en el agua de cultivo bajo diferentes tratamientos de fertilización. Letras diferentes entre las barras de la primer gráfica de estanques indica diferencias significativas $(P<0,05)$ 

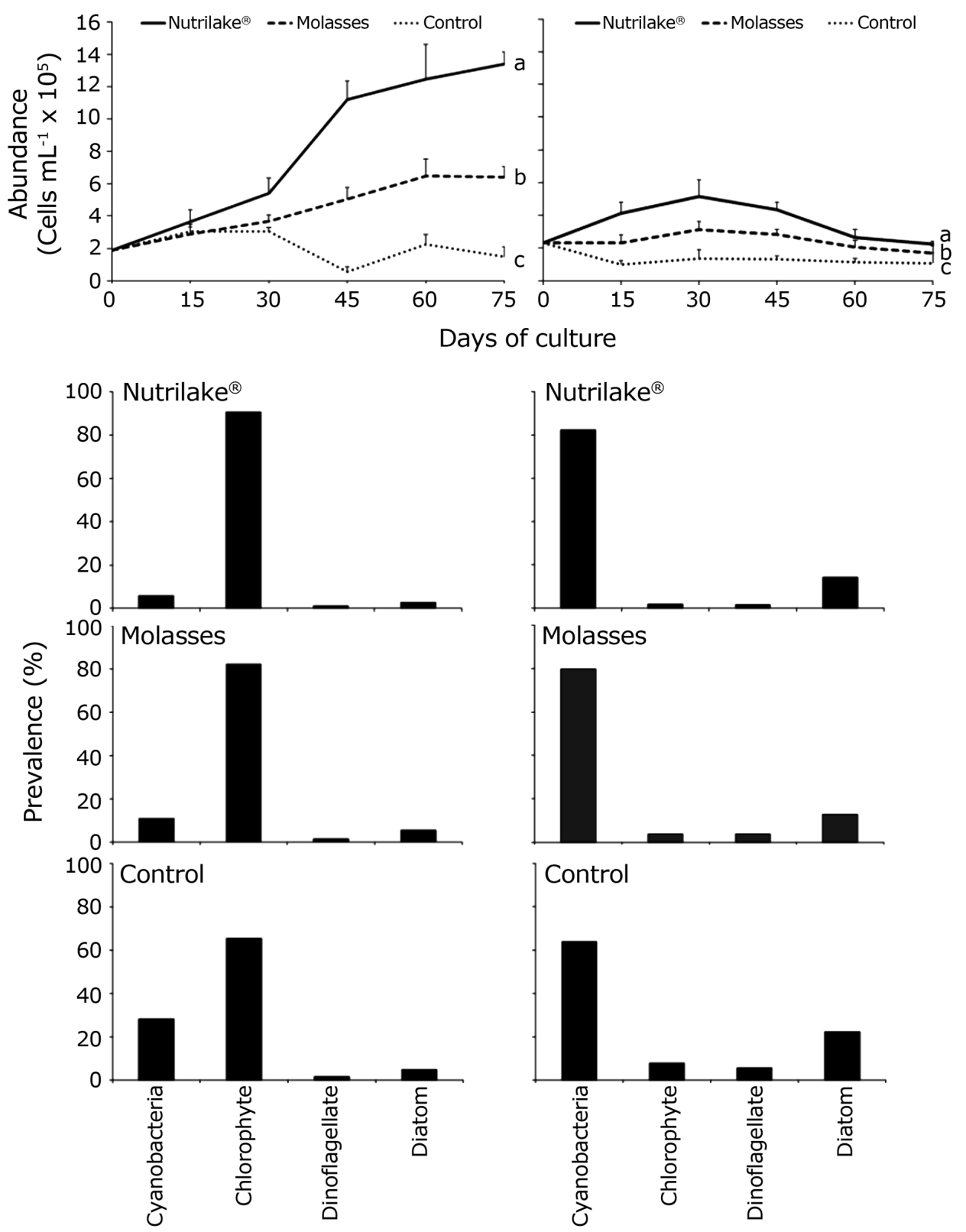

Dominant phytoplankton taxa

Figure 3. Phytoplankton abundance (mean $\pm \mathrm{SE}$ ) and dominant phytoplankton taxa (means) in the shrimp culture water under different fertilization treatments. The letters that differ among the lines indicate significant differences $(\mathbf{P}<\mathbf{0 . 0 5})$ / Abundancia de fitoplancton (media $\pm \mathrm{EE}$ ) y taxones dominantes de fitoplancton (promedios) en el agua de cultivo bajo diferentes tratamientos de fertilización. Letras diferentes entre las líneas indica diferencias significativas $(\mathrm{P}<0,05)$ 
Table 1. Water quality parameters (mean $\pm \mathrm{SE}$ ) in the tanks and ponds experiments. Within each study, the values in the same column with different superscripts differ significantly $(\mathbf{P}<\mathbf{0 . 0 5})$ / Parámetros de calidad del agua (media $\pm E E)$ de los tanques y estanques experimentales. Dentro de cada estudio, los valores en la misma columna con diferente superíndice representa diferencias significativas $(P<0,05)$

\begin{tabular}{clcccccccc}
\hline Study & \multicolumn{1}{c}{ Trial } & $\begin{array}{c}\text { Nitrite } \\
\left(\mathrm{mg} \mathrm{L}^{-1}\right)\end{array}$ & $\begin{array}{c}\text { Nitrate } \\
\left(\mathrm{mg} \mathrm{L}^{-1}\right)\end{array}$ & $\begin{array}{c}\text { Ammonia } \\
\left(\mathrm{mg} \mathrm{L}^{-1}\right)\end{array}$ & $\begin{array}{c}\text { Phosphate } \\
\left(\mathrm{mg} \mathrm{L}^{-1}\right)\end{array}$ & $\begin{array}{c}\text { OD } \\
\left(\mathrm{mg} \mathrm{L}^{-1}\right)\end{array}$ & $\begin{array}{c}\text { Temperature } \\
\left({ }^{\circ} \mathrm{C}\right)\end{array}$ & pH & Salinity \\
\hline \multirow{2}{*}{ Tanks } & Nutrilake $^{\circledR}$ & $0.05(0.01)^{\mathrm{a}}$ & $0.07(0.05)^{\mathrm{a}}$ & $0.41(0.19)^{\mathrm{a}}$ & $0.41(0.19)^{\mathrm{a}}$ & $4.98(3.61)^{\mathrm{a}}$ & $30.4(5.9)^{\mathrm{a}}$ & $8.2(0.2)^{\mathrm{a}}$ & $33(4)^{\mathrm{a}}$ \\
& Molasses $^{\mathrm{a}}$ & $0.02(0.00)^{\mathrm{b}}$ & $0.03(0.06)^{\mathrm{a}}$ & $0.23(0.09)^{\mathrm{b}}$ & $0.35(0.05)^{\mathrm{a}}$ & $4.80(3.60)^{\mathrm{a}}$ & $32.2(5.9)^{\mathrm{a}}$ & $8.0(0.2)^{\mathrm{a}}$ & $33(3)^{\mathrm{a}}$ \\
& Control & $0.02(0.00)^{\mathrm{b}}$ & $0.02(0.04)^{\mathrm{a}}$ & $0.28(0.22)^{\mathrm{a}}$ & $0.30(0.11)^{\mathrm{a}}$ & $4.90(3.50)^{\mathrm{a}}$ & $31.1(6.2)^{\mathrm{a}}$ & $8.1(0.1)^{\mathrm{a}}$ & $33(4)^{\mathrm{a}}$ \\
\multirow{2}{*}{ Ponds } & Nutrilake ${ }^{\circledR}$ & $1.10(0.30)^{\mathrm{a}}$ & $5.10(2.12)^{\mathrm{a}}$ & $1.40(0.06)^{\mathrm{a}}$ & $0.08(0.18)^{\mathrm{a}}$ & $4.70(3.60)^{\mathrm{a}}$ & $31.8(5.4)^{\mathrm{a}}$ & $8.0(0.2)^{\mathrm{a}}$ & $34(4)^{\mathrm{a}}$ \\
& Molasses & $0.40(0.11)^{\mathrm{b}}$ & $1.50(1.2)^{\mathrm{b}}$ & $0.66(0.01)^{\mathrm{b}}$ & $0.11(0.08)^{\mathrm{a}}$ & $4.50(3.60)^{\mathrm{a}}$ & $31.5(6.0)^{\mathrm{a}}$ & $8.0(0.1)^{\mathrm{a}}$ & $35(4)^{\mathrm{a}}$ \\
& Control & $0.30(0.22)^{\mathrm{b}}$ & $2.40(0.3)^{\mathrm{b}}$ & $0.69(0.03)^{\mathrm{b}}$ & $0.07(0.04)^{\mathrm{a}}$ & $4.80(3.80)^{\mathrm{a}}$ & $31.5(5.5)^{\mathrm{a}}$ & $8.1(0.1)^{\mathrm{a}}$ & $34(3)^{\mathrm{a}}$ \\
\hline
\end{tabular}

were representative of those found in shrimp culture (SilvaCampos et al. 2009). The highest phytoplankton abundances occurred in the Nutrilake $\mathrm{e}^{\circledast}$-treated groups, whereas the lowest abundances were recorded in the unfertilized groups (Fig. 3), which was as expected (Boyd 1997).

All of the physicochemical parameters recorded in both tanks and ponds experiments (Table 1) remained in appropriate levels for shrimp growth (Chien 1992, Frías-Espericueta et al. 1999). No significant differences in phosphate, temperature, $\mathrm{pH}, \mathrm{DO}$, and salinity were detected within tanks and ponds (Table 1). However, in both experiments the nitrogen concentrations differed significantly among treatments (Table 1 ). As expected, the addition of Nutrilake ${ }^{\circledR}$ resulted in higher concentrations of nitrite, nitrate and total ammonia (Table 1), but the values remained within appropriate levels for shrimp (Van Wyk \& Scarpa 1999). In the tanks, the molasses treatment reduced the total ammonia concentrations toward the experiment end, consistent with previous reports (Avnimelech 1999, Samocha et al. 2007). However, in the ponds experiments the same effect was not observed.

\section{ACKNOWLEDGMENTS}

This study is part of the projects funded for the Instituto Politécnico Nacional (SIP-20100145, SIP-20110581).

\section{LITERATURE CITED}

Allan GL, JM Moriarty \& GB Maguire. 1995. Effect of pond preparation on production of Penaeus monodon Fabricius farming ponds. Aquaculture 130: 329-349.

Anónimo. 1998. Muestreo poblacional en el cultivo de camarón, I parte: Uso de atarraya. Boletín Nicovita 3(3): 1-2. <http:/ /www.nicovita.com/extranet/Boletines/mar_98_03.pdf>
Avnimelech Y. 1999. Carbon/nitrogen ratio as a control element in aquaculture systems. Aquaculture 176: 227-235.

Avnimelech Y, S Mokady \& GL Scroeder. 1989. Circulated ponds as efficient bioreactors for single cell protein production. The Israeli Journal of Aquaculture, Bamidgeh 41: 58-66.

Boyd CE. 1997. Practical aspects of chemistry in pond aquaculture. Progressive Fish-Culturist 59: 85-93.

Chien YW. 1992. Water quality requirements and management for marine shrimp culture. In: Wyban J (ed). Proceedings of the Special Session on Shrimp Farming, pp. 144-156. Word Aquaculture Society, Baton Rouge.

Frías-Espericueta MG, H Harfush-Meléndez, JI OsunaLópez \& F Páez-Osuna. 1999. Acute toxicity of ammonia to juvenile shrimp Penaeus vannamei Boone. Bulletin of Environmental Contamination and Toxicology 62: 646-652.

Hallegraeff GM, DM Anderson \& AD Cembella. 2003. Manual on harmful marine microalgae, 794 pp. UNESCO, París.

Janeo RL, VL Corre Jr \& T Sakata. 2009. Water quality and phytoplankton stability in response to application frequency of bioaugmentation agent in shrimp ponds. Aquacultural Engineering 40: 120-125.

Martínez-Córdova L. 1999. Cultivo de camarones peneidos: Principios y prácticas, 298 pp. AGT Editor, México.

Martinez-Cordova LR, A Campaña-Torres \& MA PorchasCornejo. 2002. Promotion and contribution of biota in low water exchange ponds farming blue shrimp Litopenaeus stylirostris (Stimpson). Aquaculture Research 33: 27-32.

Newell GE \& RC Newell. 2006. Marine plankton: a practical guide, 206 pp. Hutchinson Educational Editions, University of London, London.

Ray AL, KS Dillon \& JM Lotz. 2011. Water quality dynamics and shrimp (Litopenaeus vannamei) production in intensive, mesohaline culture systems with two levels of biofloc management. Aquacultural Engineering 45: 127-136. 
Samocha TM, S Patnaik, M Speed, AM Ali, JM Burger, RV Almeida, Z Ayub, M Harisanto, A Horowitz \& DL Brock. 2007. Use of molasses as carbon source in limited discharge nursery and grow-out systems for Litopenaeus vannamei. Aquacultural Engineering 36: 184-191.

Shishehchian F \& FM Yussof. 1999. Composition and abundance of macrobenthos in intensive tropical marine shrimp culture ponds. Journal of the World Aquaculture Society 30: 128-133.

Silva-Campos S, U Lima-Silva, MZ Tabosa-Lúcio \& E de Souza-Correira. 2009. Natural food evaluation and water quality in zero water exchange culture of Litopenaeus vannamei fertilized with wheat bran. Aquaculture International 17: 113-124.

Sournia A. 1978. Phytoplankton manual, 337 pp. UNESCO, Paris.

Strickland JDH \& TH Parsons. 1972. A practical handbook of seawater analysis. Bulletin, Fisheries Research Board of Canada 167: 1-310.

Thakur DP \& CK Lin. 2003. Water quality and nutrient budget in closed shrimp (Penaeus monodon) culture systems. Aquacultural Engineering 27: 159-176.

Todd CD, MS Laverack \& GA Boxshall. 1996. Coastal marine zooplankton: A practical guide, 106 pp. Cambridge University Press, New York.
Tomas CR. 1997. Identifying marine phytoplankton, 858 pp. Academic Press, San Diego.

Van Wyk P \& J Scarpa. 1999. Water quality requirements and management. In: Van Wyck P (ed). Farming marine shrimp in recirculating freshwater system, pp. 128-129. Florida Department of Agriculture and Consumer Services, Tallahasee.

Venero JA, DA Davis \& DB Rouse. 2007. Variable feed allowance with constant protein input for the pacific white shrimp Litopenaeus vannamei reared under semi-intensive conditions in tanks and ponds. Aquaculture 269: 490-503.

Wang JQ, D Dong, S Wang \& X Tian. 1998. Experimental studies on polyculture in closed shrimp ponds. I. Intensive polyculture of Chinese shrimp (Penaeus chinensis) with tilapia hybrids. Aquaculture 163: 11-27.

Wheeler PA \& DL Kirchman. 1986. Utilization of inorganic and organic nitrogen by bacteria in marine systems. Limnology and Oceanography 31: 998-1009.

Zar JH. 1996. Biostatistical analysis, 663 pp. Prentice Hall, Englewood Cliffs. 